\title{
B. Anhaug.
}

Geite

I. Stubienpläne . . . . . . . . . . . . . . . . 215

II. Rromotionsెorbnungen . . . . . . . . . . . . . 223

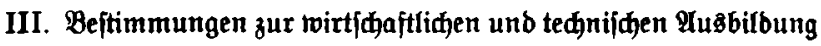
ber StaatBbienftafpiranten. . . . . . . . . . . . 232

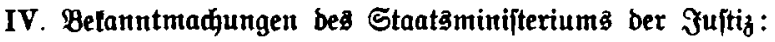

1. bom 20. Februar 1909, bie Sibgungâtleioung ber Recht: prattifanten betr.,

2. vom 17. Dezember 1906, baß Melbeber|ahren betr., . 24 כ̃

V. Borbebingungen für anbere - im Sauptteile nidjt berüd= fidhtigte - höhere ม̈mter . . . . . . . . . . . . 246

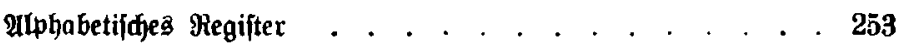

\section{Hadtrag.}

Die auf Seite 246 angefïhrten Boridgriften über bie Bor

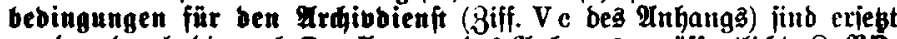
worben burd bie nad Drudlegung bez 2 nhang 3 beröffentlidite $\Re$. $B D$. vom 3. Sttober 1911 über bie Borbebingungen für bin höheren itaat = fiden Prdjibbienft (GBBBI. $1061 \mathrm{ff}$.). 